Institut Agama Islam Negeri (IAIN) Curup, Indonesia
ISSN 2775-8621
volume 1, number 1, 2021

\title{
Legal Study of The Existence of Genuine Autonomy in Order to Organize Village Autonomy in Indonesia
}

\author{
David Aprizon Putra ${ }^{1}$ M. Anton Alifandi ${ }^{2}$ \\ Institut Agama Islam Negeri (IAIN) Curup, Indonesia \\ davidaprizonputra@iaincurup.ac.id, muhammadanton660@gmail.com
}

\begin{abstract}
The centralized system implemented by the New Order government made the central to regional movements only as the form of exploitative movements. Meanwhile, the movement from the regions to the center has only become an enslaving movement. This fact then became the basis for the formation of genuine autonomy, which seeks to turn imperial cosmopolitanism into micro-politics in the form of regional autonomy. This was followed by the birth of Village autonomy in 2014, which certainly brought fresh air in the governance development order in Indonesia. The effort to restore the essence of genuine autonomy, which is indeed a pure value that has existed and belonged to the archipelago, is one of the gold goals for implementing this village autonomy. This legal research uses a normative-sociological approach based on statutory data, literature studies and history. There are many significant things related to strengthening the existence of Genuine Autonomy/Village Autonomy in Law Number 6 of 2014 concerning Villages. We can see this in terms of: Regarding the definition of village (Article 1 point 1), Setting 10 percent of APBN funds to be allocated to the Village, Regarding to the evolution of village authority (Articles 18 and 19), Regarding the portion of village rights [Article 6 act (1)], Regulation on Village-Owned Enterprises (Article 87). There are several things we can do in an effort to maintain the existence of genuine autonomy/village autonomy in Law Number 6 of 2014 concerning Villages: 1). Legislative: The need of a strong legal certainty foundation; 2). Executive: The need for Government Apparatus with integrity, professional, neutral, and noble character, Community Participation; 3). Community: Strong and Participatory Civil Society.
\end{abstract}

Keywords: Village, Genuine Autonomy, Village Autonomy. 
NEGREI : Academic Journal of Law and Govenance,

Volume 1 Nomor 12021

\section{Introduction}

Genuine autonomy is a conception of the actual condition of the Indonesian people, originating from the lives of Indonesian rural communities without being in the least contaminated by foreign substances. Talking about village governance, then we would be unfair if we didn't focus on past history, because this is where we can find a complete original concept of autonomy. Soetardjo Kartohadikoesoemo said that village government in Indonesia had existed for hundreds of years. (Soetardjo Kartohadikoesoemo,1997) This means that village government in Indonesia has existed since pre-independence times. The current village government is a continuation of the past village government journey, with various kinds of evolutions that have occurred, especially before Law Number 6 in 2014 concerning Villages, hereinafter referred to as Law 6/2014, so that now village government in Indonesia has lost its identity and soul. The village government owned by Indonesia is no longer the volksgemeen chappen as in the form of government carried out in the Dutch era. Such conditions make the existing village government can be said to be a pseudo or shadow government/quasi-government organization ( Sadu Wastiono and M. Irwan Tahir, 2006). If the mandate of the law is truly implemented in the implementation of Regional Autonomy, then regional autonomy will become a powerful weapon in the process of developing this country (David Aprizon Putra, 2016).

A new hope as well as a beautiful gift was born at the end of 2013. The most beautiful gift is also a legacy of the last legislation of the SBY-Budiono government. We should be happy about this, because one of the branches of new hope towards changing Indonesia for the better is there. On 18 December 2013, Law 6/2014 was officially ratified by the House of Representatives of the Republic of Indonesia. Broadly speaking, this Village Law regulates various directions for the implementation of pure village autonomy (in this paper the author calls it as genuine autonomy). Several urgent matters that dominantly appear in this Law include the provision of $10 \%$ of the APBN to villages, the fixed salary system received by village officials including the BPD (Village Consultative Body), the mandate for the establishment of BUMDes and a 6-year position for the Village Head which can be continued for 2 periods, or a maximum 18 years of leadership in the Village. These are new things that have emerged in Law 6/2014, and are in stark contrast to the different regulations governing the Village with the mother (Law number 32 of 2004 concerning Regional Government, hereinafter referred to as Law 32/2004) and there is new hope. The hope for change was actually opened in this reform era with the 


\section{David Aprizon Putra, M. Anton Alifandi Legal Study of The Existence of Genuine Autonomy in Order to Organize Village Autonomy in Indonesia}

issuance of Law Number 22 of 1999 concerning Regional Government which was revised into Law 32/2004. However, it seems that the law has not been able to return the true existence of the village as the lowest level of government that has the right to regulate its own household without leaving customs. The birth of the village law became the entry point for changes to the chaotic regional development that had made the village as an object of sufferers. So far, Law $32 / 2004$ is considered to have placed the position of the village in an ambivalent and unclear position.

Law 6/2014 emphasizes "genuine autonomy" as a principle of village governance. "Genuine Autonomy" is identical to the customary law community unit, but from the authority given, it shows the village as an administrative unit or government unit, so it can be said that the format of village autonomy according to Law 32/2004 is mixed. With the establishment of this Village Law, it is clear where the system and structuring of our country's government will be directed, as well as which legal politics we have chosen. Hopefully we are not mistaken in believing this. One certain thing is that the main focus of the government is to achieve the welfare of the nation and state, creating a prosperous and just society in terms of welfare without exception. Legal political choices will play a very strong role there, with the birth of Law 6/2014. Accuracy in determining which direction to choose will be the most important part in achieving the country's goals. In this paper, the author will try to analyze the existence of genuine autonomy in Law 6/2014 as well as conduct a normative speculation regarding what efforts we can do to achieve the implementation of the genuine autonomy.

The relationship between the central government and local governments is carried out using the principles of decentralization, deconcentration and coadministration principles. These three principles form the legal basis for the implementation of governance by the central government and local governments as explained below, regarding the actions of the central government on its authority to regulate regional government..

Originally in the literature of the United States, Harold F. Alderfer revealed that there are two general principles in distinguishing how the central government allocates its power down. The first is in the form of deconcentration, which merely compiles administrative units or field assignments, either singly or in a hierarchy, either separately or combined, with instructions on what they should do or how to do it. No policies are made at the local level and no fundamental decisions are taken, central agencies have all the power within themselves, while local officials are completely local subordinates and they only carry out orders. 
NEGREI : Academic Journal of Law and Govenance,

Volume 1 Nomor 12021

Second, in the form of decentralization where local units are assigned with certain powers over certain areas of duty, they can carry out their own judgment, initiative and governance (DPR RI, 2011).

The central government will be the holder of the highest power and stand alone. The relationship that occurs between the central and local governments is in the form of implementing orders from the central government by local governments. The relationship between the central government and regional governments is contained in Article 18A act (1) and 18B act (1) of the 1945 Constitution. The provisions in Article 18 of the 1945 Constitution, both before the amendment and after the amendment, are the constitutional basis for the implementation of regional government.

According to Bagir Manan, article 18 of the 1945 Constitution before the amendment had several principles (Bagir Manan, 1994):

1. The principle of territorial decentralization. The territory of Indonesia will be divided into government units arranged in large and small regions. The 1945 Constitution does not regulate functional decentralization.

2. Orders to legislators (President and House of Representatives) to regulate territorial decentralization in the law (organic law).

3. Orders to legislators in drafting laws on decentralization.

According to Article 18 act (1) to act (6) of the 1945 Constitution, the State adheres to the concept of a decentralized unitary state. This means that although the Indonesian state is in the form of a unitary state, in the implementation of state government, there is a division of delegation of authority or government affairs by the central government to local governments. The delegation of authority or affairs aims to give the authority to regulate regional households independently, in accordance with the conditions and capabilities of each region so that efforts to create prosperity can be achieved evenly and fairly.

B.C. Smith gave his opinion on the concept of decentralization (B.C. Smith, 1985): Decentralization entails the subdivision of the state's territory into smaller areas and the creation of political and administrative institution in those areas. Some of the institution so created may themselves find it necessary to practice further decentralization

It is very clear that the main concept of implementing decentralization is the split or division of large (central) government area so that they have smaller government areas (regions), in which according to Smith there are also 


\section{David Aprizon Putra, M. Anton Alifandi Legal Study of The Existence of Genuine Autonomy in Order to Organize Village Autonomy in Indonesia}

institutions that become government organs in the regions, and there are administrative arrangements that appropriate to the needs of each region. By carrying out these two stages, it is hoped that regional needs and problems will be covered in more detail and resolved properly.

Based on the background above, there are two problems that will be discussed in this paper:

1. What is the fundamental difference between the concept of Village Autonomy in Law Number 6 of 2014 concerning Villages and Law Number 32 of 2004 concerning Regional Government in order to find the existence of Genuine Autonomy?

2. What are the efforts that can be made to re-implement the genuine autonomy optimally?

In order to answer the two problems above, research method that is suitable and in accordance with the needs of the problem is used. This legal research uses a normative-sociological approach based on statutory data, literature studies and history. Approaches to theories, concepts, principles, norms and doctrines related to the discussion themes will be carried out, both from books, legislation, jurisprudence, scientific journals and other sources deemed relevant. The historical data approach cannot be separated in the discussion of this paper, considering that genuine autonomy is one of the legal literacy studies that is full of history, even since the time before the Republic of Indonesia existed

\section{Authentic Autonomy and Vilage Autonomy}

\section{Definition of Village}

Genuine Autonomy is another word for Village Autonomy. The author prefers to use genuine autonomy word because it literally gives a better grammatical understanding than the word village autonomy. Genuine Autonomy will be able to provide a direct description of the intended meaning, namely the authenticity and purity of the values contained in the autonomy, the genuine and pure autonomy of each village. Village according to H.A.W. Widjaja in his book entitled "Village Autonomy" states that (H.A.W. Widjaja, 2004) :

Village is a legal community unit that has an original structure based on special origin rights. The rationale for village governance is diversity, participation, genuine autonomy, democratization and community empowerment. 
NEGREI : Academic Journal of Law and Govenance,

Volume 1 Nomor 12021

The previous law governing Villages, namely Article 1 act (12) of Law 32/2004 defines Village as follows:

Village or what is called another name, hereinafter referred to as village, is a legal community unit that has territorial boundaries that are authorized to regulate and manage the interests of the local community, based on local origins and customs that are recognized and respected in the system of the Government of the Unitary State of the Republic of Indonesia. .

From the definitions of village according to Widjaja and Law number 32 of 2004 above, it is very clear that the village is a self-community, a community that regulates itself. With the understanding that the village has the authority to manage and regulate the interests of its community in accordance with local conditions and socio-cultural conditions, the position of the village that has genuine autonomy is very strategic so that it requires balanced attention to the implementation of Regional Autonomy because strong Village Autonomy will significantly affect the realization of Regional Autonomy. Moreover, in the definition that exists in Law 6/2014, there are additions that ultimately strengthen the existence of genuine/village autonomy.

Villages have the authority as stated in Government Regulation No. 72 of 2005 concerning Villages, namely:

a. Carrying out existing government affairs based on village origin rights.

b. Organizing government affairs which are the authority of districts/cities whose arrangements are handed over to the village, namely the government affairs that can directly improve public services.

c. Assistance tasks from the government, Provincial Government, and Regency/City Government.

d. Other government affairs which by law are handed over to the village.

We are still waiting, what kind of Government Regulation will be issued after the issuance of the new Village Law.

The purpose of forming a village is to improve the ability to administer government in an efficient and effective manner and to improve services to the community in accordance with the level of development and progress of development. In creating development up to the grassroots level, there are several conditions that must be met for the formation of a village: First, the population factor, at least 2500 people or 500 families. Second, the factor of area that is affordable in community services and development. Third, the location factor 


\section{David Aprizon Putra, M. Anton Alifandi Legal Study of The Existence of Genuine Autonomy in Order to Organize Village Autonomy in Indonesia}

which has a communication network or inter villages communication. Fourth, infrastructure factors: the availability of transportation, marketing, social, production, and village government facilities. Fifth, socio-cultural factors: the existence of harmony in religious life and community life in customary relations. Sixth, community life factors, namely a place for community livelihood needs..

\section{The Concept of Genuine/Village Autonomy}

States that village autonomy is genuine, unanimous, and complete autonomy and is not a gift from the government (H.A.W. Widjaja, 2004). On the other hand, the government is obliged to respect the genuine autonomy of the village. As a legal community unit that has an original structure based on privileges, the village can carry out legal actions, both public law and civil law, own wealth, property and can prosecute and be prosecuted in court. With the commencement of the issuance of Law Number 22 of 1999 which was later refined by the issuance of Law Number 32 of 2004 concerning Regional Government, it provided a strong foundation for the village in realizing a "Development Community" in which the village is no longer an administrative level or subordinate to the region but instead as an "Independent Community". It means that the village and its community have the right to speak in the interests of their own community. Villages are given the authority to regulate their villages independently, including in the social, political and economic fields. With this independence, it is hoped that it will increase the participation of rural communities in social and political development.

For villages, the autonomy they have is different from the autonomy possessed by the provinces as well as districts and cities. The autonomy possessed by the village is based on its origins and customs, not based on the delegation of authority from the Government. Village or any other name, hereinafter referred to as village is a legal community unit that has the authority to regulate and manage the interests of the local community based on local origins and customs which are recognized in the National Government system and are located in the Regency Area.

The rationale that needs to be developed at this time is diversity, participation, genuine autonomy, democracy, and community empowerment. Recognition of autonomy in the village is explained by Taliziduhu Ndraha as follows:

a. Village autonomy is classified, recognized, fulfilled, trusted and protected by the government, so that the dependence of rural communities on the "generosity" of the government can be reduced. 
NEGREI : Academic Journal of Law and Govenance,

Volume 1 Nomor 12021

b. The position and role of the village government is restored, returned to normal or developed so that it can anticipate the future.

Village autonomy is the right, authority and obligation to regulate and manage own government affairs and the interests of the community based on the rights of origin and socio-cultural values that exist in the community to grow and develop following the development of the village. Government affairs based on the origin of the village and affairs that are the authority of the Regency or City government are handed over to the village. However, it must always be remembered that there are no rights without obligations, no authority without responsibilities and no freedom without limits.

Therefore, in the implementation of rights, authorities and freedoms in the implementation of village autonomy, it is necessary to uphold the values of responsibility to the Unitary State of the Republic of Indonesia by emphasizing that the village is an inseparable part of the Indonesian nation and state. The implementation of the rights, authority and freedom of village autonomy requires the responsibility to maintain the integrity, unity and integrity of the nation in the bonds of the Unitary State of the Republic of Indonesia and the responsibility to realize the welfare of the people which is carried out within the corridors of the applicable laws and regulations (H.A.W. Widjaja, 2004).

\section{Broad, Real and Responsible Autonomy}

The decentralization policy reform was first introduced through Law Number 22 of 1999 concerning Regional Government and Law Number 25 of 1999 concerning Financial Balance between Central and Regional Governments, which was then followed by Law Number 32 of 2004 concerning Regional Government and Law No. Law Number 33 of 2004 concerning Financial Balance between Central and Regional Governments which is intended so that regions are able to regulate and manage the interests of the community according to their own initiatives based on people's aspirations and in accordance with the laws and regulations in the system of the Unitary State of the Republic of Indonesia. The granting of autonomy authority must be based on the principle of decentralization and implemented with broad, real, and responsible principles (Hari Sabarno, 2007). Government Regulation Number 72 of 2005 Article 7 letter $\mathrm{b}$ also provides a description of the implementation of village autonomy in a broad, real, responsible manner, in which it is stated that government affairs under the authority of the district/city are handed over to the village. Regency/Municipal. Governments identify, discuss, and determine the types of authority whose regulations are delegated to the village, such as authority in 


\section{David Aprizon Putra, M. Anton Alifandi Legal Study of The Existence of Genuine Autonomy in Order to Organize Village Autonomy in Indonesia}

agriculture, energy mining, forestry and plantations, industry and trade, cooperatives, manpower.

The authority of broad autonomy is the area's freedom to administer government which includes the authority of all areas of government, except for the authority in the fields of foreign policy, defense and security, justice, monetary and fiscal, religion, as well as other fields of authority (as stipulated by Government Regulation No. 25 of 2000). Moreover, the scope of autonomy includes complete and unanimous authority in the execution of planning, implementation, supervision, control and evaluation (Hari Sabarno, 2007). The broad definition of the implementation of regional autonomy is the area's freedom to administer government which covers all areas of government except for the fields of foreign policy, defense and security, justice, monetary and fiscal, and religion, as well as other fields of authority. The other areas of authority include policies on national planning and control of macro-national development, financial balance funds, state administration systems and state economic institutions, development and empowerment of human resources, utilization of natural resources and strategic high technology, conversion, and national standardization.

Real autonomy is the freedom of the region to carry out government authority in certain fields that are actually there and needed and grow, live and develop in the region. The local government in addition to playing a role in protecting the community and absorbing the aspirations of the community must also be able to manage the various authorities given to it by the central government. In the management of this broad authority, important signs remain within the framework of the Unitary State of the Republic of Indonesia. In this case, autonomy doesn't not only use administrative approach or just increasing work efficiency and effectiveness, but also use the political dimension approach at the same time. Thus, the meaning of authority in the field of government that is directly related to the interests of the community as far as possible must be served closely and quickly. Responsible autonomy is the realization of accountability as a consequence of granting rights and authorities to regions in the form of duties and obligations that must be borne by regions in achieving the objectives of granting autonomy, in the form of improving public services and welfare, developing democratic life, justice and equity and maintenance of harmonious relations between the center and the regions as well as between regions in the context of maintaining the integrity of the Unitary State of the Republic of Indonesia. 
NEGREI : Academic Journal of Law and Govenance,

Volume 1 Nomor 12021

\section{Analysis of law number 6 of 2014 on village towards law number 32 of 2004 on regional government in order to find the existence of genuine autonomy}

In fact, Law Number 32 of 2004, especially Chapter XI which regulates Village, has perfected the rules on Village regulated in Law Number 22 of 1999. However, in its implementation, several problems still arise.

First, Law Number 32 of 2004 has not clearly regulated the arrangement of authorities between the Government, Regional Government, and Villages. Based on the principles of decentralization and broad autonomy espoused by Law Number 32 of 2004, the Government only exercises five powers, and outside of these five, it becomes the authority of the regions. Thus, the basic concept adopted by Law Number 32 of 2004 is that autonomy stops at districts/cities. Consequently, further regulation of the Village is carried out by the district/city, where the authority of the Village is the authority of the district/city which is handed over to the Village. The spirit of Law Number 32 of 2004 which positions the Village under the Regency is not coherent and congruent with the other breaths in Law Number 32 of 2004 which actually recognizes and respects the genuine authority that comes from the right of origin. This recognition of the authority of origin shows that Law Number 32 of 2004 adheres to the principle of recognition. The consequence of the recognition of "genuine autonomy" is that the Village has the right to regulate and manage its own household based on local origins and customs (self governing community), and is not an authority delegated by the superior government to the Village. The existance of those two principles in the regulation creates ambivalence in placing the position and authority of the Village. The unclear position and authority of the Village causes Law Number 32 of 2004 to not be strong enough to lead to the achievement of the ideals of an independent, democratic, and prosperous Village. There are many views that say that now the original autonomy has been lost because all government affairs have become the property of the state; there is not a single government affair that escapes state regulation. For many people who have gone beyond the genuine autonomy perspective, they convey and demand the granting (decentralization) of autonomy to the Village from the state, namely the distribution of authority and greater finances. During the colonial era, for example, Article 14 of the Revenue-Instruction clearly stated that the Village Head had obligations relating to village income broadly. Even Article 74 emphasized that the responsibility for Village Taxes is in the hands of the Village Head and various other authorities, for example in the field of law enforcement. In terms of welfare, Law Number 32 of 2004 has indeed brought a vision of 


\section{David Aprizon Putra, M. Anton Alifandi Legal Study of The Existence of Genuine Autonomy in Order to Organize Village Autonomy in Indonesia}

welfare through the institutional design of regional autonomy. But the vision of welfare has not been clearly stated in the village regulations.

Second, the design of village government institutions is not perfect as a vision and policy to build independence, democracy, and village welfare. The issue of diversity, for example, always invites questions about its institutional format and design. Although Law No. 22 of 1999 and Law No. 32 of 2004 promote diversity, many people consider that the design adopted is still the default village, so that it does not provide space for optional villages that are in line with local diversity. The standard format is an administrative village (the local state government) which is certainly not a traditional village that has genuine autonomy (selfgoverning community) and not an autonomous village (local self-government) like an autonomous region. Law Number 32 of 2004 does not place the village in an autonomous position, and does not allow the formation of a customary village alone without the presence of an administrative village. Both Law No. 22 of 1999 and Law No. 32 of 2004 place the village as part of the district/city government (subsystem). The administrative village position has consequences for the limited authority of the village, especially in the planning and financial processes. The authority of origin (genuine) is difficult to be translated and identified because of its diversity. The authority in the areas of government that is delegated by/from the district is more of a residual authority which cannot be implemented by the district/city and contains many burdens because it is not accompanied by proper funding. In terms of development planning, the village is only a part of regional planning which is normative-methodologically taken in a participatory manner and starts from the bottom (bottom up). Every year the village is required to hold a Musrenbangdes to propose a plan to the district. In empirical practice, the process does not make a participatory planning because the village planning contained in the Musrenbang is only a completeness document in the Regency/Municipal Musrenbang process.

Third, the design of Law Number 32 of 2004 concerning villages is too general so that the articles on villages can only be implemented after the issuance of Government Regulations and Regional Regulations. This tendency makes the implementation of authority to the village becomes highly dependent on the speed and capacity of the Government and local governments in making further village arrangements.

Currently we have a new law that regulates villages. In the Law on Village we will find several provisions which of course will still have to be described in the regulations below and the expectations are in line with the relevant laws and regulations. We can say that some of the provisions contained in this village law 
NEGREI : Academic Journal of Law and Govenance,

Volume 1 Nomor 12021

can already represent the spirit of genuine autonomy. The following are the things that the author criticizes and analyzes:.

\section{Regarding the definition of village}

In Law 6/2014 Article 1 point 1, the definition of Village is slightly different from the definition of Village in Law 32/2014:

Village or what is called by another name, hereinafter referred to as a village, is a legal community unit that has territorial boundaries that is authorized to regulate and manage the interests of the local community, based on the rights of origin, customs and socio-culture of the local community as long as they are still alive and in accordance with the development of society and the principles of the Unitary State of the Republic of Indonesia.

In this article 1 point 1 power to bring back the genuine autonomy is very strong. Strictly speaking, this article provides the main weapon to revive and re-execute the genuine autonomy. It gives a portion of the existence of local indigenous peoples by applying every social life based on the rights of origin, customs and their respective socio-cultural. On a legal basis, the village community already has good power in terms of formulating the definition of the village.

\section{10 percent of $A P B N$ funds will be allocated to Villages}

The regulation of 10 percent of the APBN into Village rights is an extraordinary and courageous step taken by the government. This arrangement is the one that has been fought for a very long time. This is one of the most striking issues related to the differences in Village arrangements in Law 32/2004 and Law 6/2014. Obviously this has a scientific reason as well as a good legal and political explanation. The government will not be able to immediately take this step without reasons. There are initial pros and cons related to this crucial issue, ranging from the issue of inappropriate allocation to the vote of no confidence toward the head village later on, and trauma to the excessive practice of regional autonomy.

Nevertheless, in the end the government believed that it was the right move. With such an arrangement, it is estimated that the Village will receive a disbursement of 1 billion each year. If this is true, many things will change later. The development will move by induction, from the bottom to top (bottom up). We will see a new pattern of development in Indonesia later. One positive thing that is certain to happen is the impact that will be felt by the village community; the direct touch of the village community by government aid. There will be a cut in 


\section{David Aprizon Putra, M. Anton Alifandi Legal Study of The Existence of Genuine Autonomy in Order to Organize Village Autonomy in Indonesia}

the financial accountability traffic lane, which has always been through the provincial and district governments.

One other advantage is that, by reducing the scope of government (village), monitoring efforts will be felt more reliable to be carried out optimally and massively. The participation of villagers is the main key. Not only the supervision will be repressive later, but at the beginning the villagers must also be observant and smart in choosing the village apparatus (repressive supervision). The problem of managing village finances sourced from the APBN will be assisted by sources as described in the side column; there are many sources that can be a source of village income. Another interesting thing is regarding to the management of village resources independently.

\section{Regarding the evolution of village authority}

In Law 6/2014 there has been a massive evolution regarding the authority of the Village, this is explained in Articles 18 and 19:

Article 18: Village authority includes authority of village administration, implementation of village development, village community development, and empowerment of village communities based on community initiatives, rights of origin and customs.

In Article 18, it is clear that the effort to strengthen the rights of origin and customs as represented by the phrase "community initiatives" is a weapon for the village government to be able to strive for the existence of village autonomy that it originally has, so it is strong and based on law. Obviously this will facilitate the implementation of village autonomy in accordance to the interests of the villagers later. Then article 19 describes in detail what things that become the authority of the Village:

Article 19 :

The authority of the village includes:

a. the existing authority based on the rights of origin, customs and socio-cultural values of the community;

b. village-scale local authority recognized by the district/city;

c. the authority of the central, provincial and district/city governments whose implementation is delegated to the village; and

d. other authorities as determined by the laws and regulations. 
NEGREI : Academic Journal of Law and Govenance,

Volume 1 Nomor 12021

The authority of the central, provincial and district/city governments whose implementation is delegated to the village is the delegation of authority to the head village as an institution and the village government administrator. In carrying out the authority, it is accompanied by financing and accountability for implementation. Judging from this article, the author sees that the government framework still cannot considered as genuine autonomy because with the existence of this article, it is very possible that conflicts of interest will occur again later, between the government and the village government.

\section{Regarding the portion of village rights}

Article 6 act (1) of Law 6/2014 regulates village rights:

The village has the rights: To regulate and manage the interests of the community based on the rights of origin, customs and socio-cultural values of the community;

a. To regulate and manage village institutions;

b. To obtain the source of village income.

This article really represents genuine autonomy, and this will be one of the strengths of the village government later in implementing and defending the interests of the village community. The rights of origin, customs and indigenous socio-cultural values of the local community will be the touchstone of all government implementation.

\section{Village Owned Enterprises}

One of the most striking issues regarding the difference between Law 6/2014 and Law 32/2004 is the issue of Village Owned Enterprises (BUM-Des). Article 87 which consists of 3 acts, states:

(1) Villages may establish Village-Owned Enterprises referred to as BUM Des.

(2) BUM Des is managed in a spirit of kinship and mutual cooperation.

(3) BUM Des can run a business in the economic sector and/or public services in accordance with the provisions of laws and regulations.

Villages can establish a Village Owned Enterprises (BUM Des) in the form of village businesses. The establishment of BUM Des is determined by village regulations and adjusted to the capacity and needs of the village community. Villages can only establish 1 (one) BUM Des with several business units. BUM 


\section{David Aprizon Putra, M. Anton Alifandi Legal Study of The Existence of Genuine Autonomy in Order to Organize Village Autonomy in Indonesia}

Des can be established by 2 (two) or more villages determined by joint regulations and domiciled in one of the villages based on an agreement.

With this provision, it is very possible that village development with a bottomup way will be realized. Article 87 of Law 6/2014 is one of the motivators for each village, especially the village head and his apparatus in terms of realizing economic or other business related to BUM-Des later, as well as creating a positive competitive climate between villages.

\section{Efforts that can be made to re-implement the genuine autonomy optimally}

In the implementation of village autonomy, one of the main agenda to be implemented is a bureaucratic reform. Currently every village has the right to have independence in advancing its society democratically in the fields of politics, economy, and culture. It requires a bureaucracy that is reformist, efficient, creative, innovative, and able to answer challenges in facing uncertainties in the present and in the future. With the implementation of village autonomy that prioritizes decentralization and democracy, there is a great hope that the village government can increase its accountability by giving accountability for the results of their work to the community. In one of the principles of implementing village autonomy, namely the implementation of broad, real and responsible autonomy, including the delegation of authority for government affairs, the village government has the authority to regulate government affairs that are delegated from the district/city.

In the implementation of that village governance, it is required to possess the aspect of good governance, in which one of the main characteristics or elements of good governance is accountability. Accountability can be interpreted as a form of responsibility for implementing the organization's mission in achieving the goals that have been set through the medium of accountability which is carried out periodically. So, government accountability is needed to support the implementation of village autonomy so that it can run well. An autonomous village will provide wide space for development planning which is the real need of the community and is not burdened by work programs from various agencies and the government. Each village has unique conditions and potentials, different from other villages, as well as the aspirations and character of the community.

Therefore, development in the village should be more determined by the village community itself. The position of the village government has been given full authority to empower the community and of course must have the ability to 
NEGREI : Academic Journal of Law and Govenance,

Volume 1 Nomor 12021

manage their own household by prioritizing the rights of the community. Thus it can be seen clearly that one of the essences of implementing village autonomy is directed as a vehicle to realize the active participation of the community in development towards an advanced, independent, prosperous, and just society. From this essence, there arises an obligation to carry out community empowerment in which one of the specific objectives is proclaimed, namely increasing community participation in planning the decision-making process, implementation, monitoring and maintenance of development results.

In the following, the authors describe several things that will play a very important role as well as be an important factor in efforts to maintain the existence of genuine autonomy as mandated by Law 6/2014 so that our country, Indonesia, is able to create the welfare of society and the state as a whole:

\section{Legislative: The Need of a Strong Legal Certainty Foundation}

With the ratification and promulgation of Law 6/2014, it is appropriate for us to believe that the journey of regional autonomy will be better. The strengthening of the genuine autonomy values which belong to the village has been mandated by this law and this clearly has a great chance of benefiting the people. The legal basis for efforts to strengthen the genuine autonomy value in the legislation have already exists. We just have to wait for the issuance of the Government Regulation, so that Law 6/2014 can run and operate. The stronger the regulations we have, the stronger our basis will be to achieve good and strong legal certainty. And vice versa, the weaker the regulations we have, the weaker and weaker our efforts to achieve legal certainty will be.

Then, the no less important things in terms of legislation are the derivatives of legislation that will be issued by the village government later. Nationally, Law 6/2014 and its PP will be the legal protection. Regionally, on the smallest scale, the Village Regulations will be the key in terms of maintaining the existence of the genuine autonomy mandated by Law 6/2014. Special attention is needed at this level, considering that our country is a state of law, so we cannot only focus on the problem of the implementation of legal products, but also the efforts to turn these legal products into good legislation products which are often ignored.

\section{Executive: The Need of Government Apparatus with Integrity, Professional, Neutral, and Noble Character}

The bureaucracy in Indonesia is not only known to be bad at providing public services, but also has provided opportunities for the development of collusion, corruption and nepotism (KKN) practices. Thus the renewal of the concept, 


\section{David Aprizon Putra, M. Anton Alifandi Legal Study of The Existence of Genuine Autonomy in Order to Organize Village Autonomy in Indonesia}

mechanism and paradigm of the state apparatus from an elitist bureaucracy to a populist bureaucracy (people's service) must be accompanied by an increase in the professionalism and moral integrity of the government bureaucracy. Accountability of the ranks of the bureaucracy will have an impact on increasing the accountability and legitimacy of the bureaucracy itself. Bureaucratic apparatus that have these characters can synergize with bureaucratic services quickly, effectively, and with quality.

It is useless for us to have a definite and good legal basis, if the implementers are not good and are not trustworthy. Emphasis on the executive side will be the most important part in the effort to implement Law 6/2014. Due to the large number of villages and the wide territorial area, the government's work in the context of implementing checks and balances will be more complex. However, it will be easier to monitor and pay special attention to each village because it has a problem complexity that will be less than the problems in each district/city or province. The steps taken by the government as executor as well as supervisor will be carried out with more attention to detail.

\section{Community Participation: Strong and Participatory Civil Society}

Increasing public participation is an important element in realizing a clean and authoritative government. Public participation in public policy process is absolutely carried out and facilitated by the state. The public has the right to submit suggestions, to receive information, and to criticize various government policies. Criticism can be done through representative institutions, the press or directly through open dialogues with the ranks of the bureaucracy with NonGovernmental Organizations, political parties, and other social organizations which improve people's welfare in the framework of regional autonomy.

One of the weaknesses of the past administration was the strong centralization of power in the central government, so that regional potentials were managed by the central government. This policy causes very severe access because many regions are very rich in natural resources, yet in fact become pockets of national poverty. To realize the principles of good governance, regional economic policies can be used as a medium for transforming the realization of a government model that supports the growth of a democratic culture in Indonesia. The enactment of Law Number 32 of 2004 concerning Regional Government has given authority to regions to manage and advance society in politics, economy, social and culture within the framework of maintaining the integrity of the Unitary Republic of Indonesia. With the implementation of regional autonomy, the achievement of 
NEGREI : Academic Journal of Law and Govenance,

Volume 1 Nomor 12021

welfare levels can be realized more quickly so that in the end it will encourage community independence.

The implementation of regional autonomy in Indonesia can be seen as a strategy that has a dual purpose. First, the implementation of regional autonomy is a strategy in responding to the demands of the people in the regions for three main problems, namely sharing of powers, distribution of incomes, and the independence of management systems in the regions. Second, regional autonomy is intended as a strategy to strengthen the regional economy in strengthening the national economy towards the prosperity and welfare of the people.

Likewise, with greater public participation, decentralization will then affect other components of government, such as shifting the government's orientation from command and control to being oriented towards demand and public needs. This orientation will then become the basis for implementing the government's role as a stimulator, facilitator, coordinator and entrepreneur in the development process. Therefore, regional autonomy will be the right formulation if it is followed by a series of changes in the public sector. The dimensions of public sector reform are not just changes to institutional formats, but also include updating the tools used to support the running of these public institutions in an economical, efficient, effective, transparent and accountable manner so that the ideals of realizing good governance will actually be achieved.

Especially in Law 6/2014 the portion of community participation to get involved is very large. The initial step that may be needed as soon as possible is related to the development and provision of education by the government to the community in terms of knowledge of their rights and obligations related to Law $6 / 2014$. So that in the future, there will be no missing link or miss communication on the implementation of Law 6/2014 and, it is the duty of the government and all of us. 
David Aprizon Putra, M. Anton Alifandi Legal Study of The Existence of Genuine Autonomy in Order to Organize Village Autonomy in Indonesia

\section{Conclusion}

There are many significant things related to strengthening the existence of Genuine Autonomy/Village Autonomy in Law Number 6 of 2014 concerning Villages. We can see this in terms of: Regarding the definition of village (Article 1 point 1), Setting 10 percent of APBN funds to be allocated to the Village, Regarding the evolution of village authority (Articles 18 and 19), Regarding the portion of village rights [Article 6 act (1)], Regulation on Village-Owned Enterprises (Article 87). There are several things we can do as efforts to maintain the existence of genuine autonomy/village autonomy in Law Number 6 of 2014 concerning Villages: 1) Legislative: the need of a strong legal certainty foundation; 2) Executive: the need of Government Apparatus with integrity, professional, neutral, and noble character, and 3) Community Participation: Strong and Participatory Civil Society. 
NEGREI : Academic Journal of Law and Govenance,

Volume 1 Nomor 12021

\section{Bibliography}

Bagir Manan, Hubungan Antara Pusat dan Daerah Menurut UUD 1945. Jakarta : Pustaka Sinar Harapan, 1994.

B.C. Smith, Decentralization - The Territorial Dimension of The State. London : George Allen \& Unwin, 1985.

Dewan Perwakilan Daerah Republik Indonesia. Kompleksitas Administrasi Pemerintahan Dengan Pendekatan Kebijakan Regiona. Jakarta : DPR RI, 2011

Hari Sabarno, Otonomi Daerah. Jakarta : Sinar Grafika, 2007

H.A.W. Widjaja, Otonomi Desa. Bandung : Alumni, 2003

Putra, David Aprizon. "Eksistensi Sistem Hukum Perizinan Kegiatan Pertambangan Dalam Otonomi Daerah Sebagai Salah Satu Instrumen Hukum Hak-Hak Masyarakat." Legality: Jurnal Ilmiah Hukum 24.1 (2016): 12-26.

Sadu Wastiono dan M. Irwan Tahir, Prospek Pengembangan Desa. Bandung : Fokus Media, 2006

Soetardjo Kartohadikoesoemo, Desa, Jakarta : Balai Pustaha, 1997. 